\title{
CHEMISTRY
}

\section{NATURAL BITUMEN OF GEORGIAN}

\author{
Doctor Natela Khetsuriani, Head of the Laboratory of Petroleum Chemistry, Chief Research Worker; \\ PhD Esma Usharauli, Senior research worker; \\ PhD Elza Topuria, Chief research workers; \\ MS Tamar Shatakishvili, Research worker; \\ MS Maka Kopaleishvili, Research worker;
}

Georgia, Tbilisi, Tbilisi State University, Petre Melikishvili Institute of Physical and Organic Chemistry, Laboratory of Petroleum Chemistry

DOI: https://doi.org/10.31435/rsglobal_ws/28022020/6924

\section{ARTICLE INFO}

Received: 10 December 2019

Accepted: 18 February 2020

Published: 28 February 2020

\section{KEYWORDS}

natural bitumen, gas-chromatography, microelements, asphaltenes,

tar.

\begin{abstract}
Manifestations of natural bitumen are recorded in almost all regions of Georgia. The bitumen of Kari Crossing, Natanebi, Chibrevi, Baida, Polpoy-Teibi, Mirzaani and Kila-Kupra were studied. The main aromatic structures contained in organic extracts obtained from bitumen under investigation are identified, and physical and chemical characteristics, elemental composition and distribution of microelements in these organic extracts are determined. The study of microelements distribution showed that bitumen of the Kari Crossing and the Baida 2, in which the ratio $\mathrm{V} / \mathrm{Ni}$ is less than 1 stratigraphically belong to the third-generation bitumen, and the Chibrevi and Mirzaani bitumen with the ratio $\mathrm{V} / \mathrm{Ni}>1$ is of older origin and belongs to Paleozoic period. By content of oils, tars and asphaltes the bitumen under investigation belong to the asphalt type bitumen.
\end{abstract}

Citation: Natela Khetsuriani, Esma Usharauli, Elza Topuria, Tamar Shatakishvili, Maka Kopaleishvili. (2020) Natural Bitumen of Georgian. World Science. 2(54), Vol.1. doi: 10.31435/rsglobal_ws/28022020/6924

Copyright: (C) 2020 Natela Khetsuriani, Esma Usharauli, Elza Topuria, Tamar Shatakishvili, Maka Kopaleishvili This is an open-access article distributed under the terms of the Creative Commons Attribution License (CC BY). The use, distribution or reproduction in other forums is permitted, provided the original author(s) or licensor are credited and that the original publication in this journal is cited, in accordance with accepted academic practice. No use, distribution or reproduction is permitted which does not comply with these terms.

Introduction. Fast growing rates of petroleum utilization, reduction of its stocks and continuous increase of petroleum costs put the mankind in the face of necessity to search alternative sources of hydrocarbons and petroleum products. One of such sources is natural bitumen.

The geological resources of natural bitumen in the world make 260 billion tons according to estimation of the United Nations Organization. 48 billion tons of this amount are located in Canada. Fairly large amounts are recorded in Venezuela, USA, China and Russia [1]. Their distribution is stratigraphically connected to basic sediments and are found both in old and young sediments and in most cases accompany commercial petroleum deposits that is caused by their genetic unity. By chemical and fractional composition natural bitumen is multi-purpose raw material from which it is possible to receive motor fuel, petroleum oils with a high viscosity index and low freezing temperature, high-quality bituminous materials, petroleum sulfonic acids, sulphur and some metals. In addition, the obtaining of energetic gas which is used as a fuel for combustion cameras by means of gasification of bitumen is considered to be perspective. It is clear that rational use of this raw material is a matter of great economic and scientific importance. At present in America as well as in Europe and Asia hard work is carried out on improvement of heavy petroleums and natural bitumen processing and on creation of technical means for their extraction. Canada has reached special success in this respect. By stocks of natural bitumen it wins first place in the world and has 30 years of its 
extraction and processing experience. From this raw material the so-called «synthetic petroleum» can be obtained. The structure of bitumen in it is completely destroyed as a result of degradation processes. Canadian bitumen-refining factories convert to «synthetic petroleum» about 60 million tons of bitumen annually, $80 \%$ of which is transferred to the petroleum refining factories of the USA. [2-7].
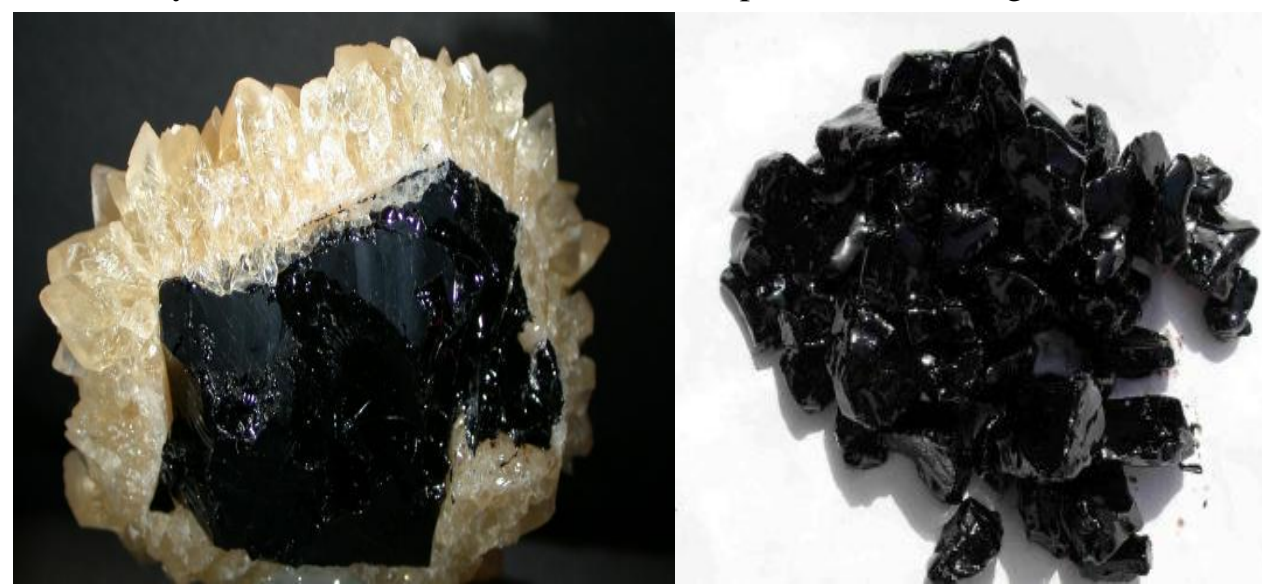

Fig. 1. Natural bitumen

Natural bitumen and petroleum deposits are widely spread in Georgia. Only in Eastern Georgia there are stated more than 2000 petroleum and almost 50 bituminous deposits [8]. As it is noted above, natural bitumen is multicomponent and multi-purpose raw material assessment of which demands the integrated, geological and chemical approach. Unfortunately, the specified manifestations were not studied sufficiently hitherto. The carried out separate researches were limited to definition of their physical and chemical characteristics and to the elementary chemical analyses which, naturally, are not sufficient for definition of prospects for bitumen utilization as alternative to petroleum raw material $[9,10,12,13]$. The purpose of the presented article is integrated state-of-the art study of bitumen and heavy petroleum on the basis of which it will be possible to obtain several petroleum products (such as kerosene and diesel fuel, gasoil, petroleum oils, some metals and bituminous materials) from natural bitumen and heavy petroleum and to solve scientific problems such as formation of bitumen and crude oil manifestations, establishment of link with crude oil deposits and mud volcanoes of the region, their migration ways, catagenic transformation degree that can be done by study of "biological labels" (biomarkers) at molecular level [14-16]. Definition of these characteristics is used for genetic and chemical typification of petroleum, for definition of its catagenic transformation degree, for realization of the most important geochemical and genetic correlations, for determination of possible age and routs of migration of hydrocarbonic fluids.

Hence the investigation of natural bitumen manifestations with the help of rational unified complex of physical and chemical methods has great economic and scientific significance for assessment of prospects of their utilization as alternative to petroleum raw material and to give answer to the set-forth scientific questions.

Purpose of the study: Research on Natural Bitumen of Georgia

Materials and methods. All used chemicals were of analytical grade. AFP silica gel activated.

Fine-Porous silica gel) - Manufacturer: Labstatus Ltd, (Ukraine); Petroleum ether (SigmaAldrich International GmbH; Germany); Dioxane (Sigma-Aldrich International GmbH; Germany); Benzene (Garlo Erba; Germany); n-Heptane (Sigma-Aldrich International GmbH; Germany); Methods of GLC and mass spectrometry; standard method for isolation of asphaltenes from petroleum with nheptane. Reference standards: phenanthrens, pyrenes, chrysenes, perylenes (Sigma-Aldrich International GmbH, Germany).

The following methods were used to conduct the studies: extraction, deasphalting, adsorption chromatography, elemental analysis, fragmentation, exchange, separation, chromatographic and emission spectroscopy.

Some of the natural bitumen of Georgia was investigated: Natanebi, Chibrevi (Racha region), Kari Crossing and Baida 2 (Kakheti region), Polpoi-teibi, Mirzaani and Kila-Cupra. Chibrevi is located in Mestia-Tianeti zone (in Oni district). The upper Cretaceous fossil rocks and tertiary deposits directly overlapping Cretaceous sediments are involved in the geological section of the zone. Baida 
and Kari Crossing are located within the adjacent to the Iori river subzone, which stretches in the form of a narrow strip along the river Iori to the north, is confined from the north by Khashmi-Eldar deep break and from the south by Erikdar regional break. The upper Sarmatian up to the Oligocene fossil rocks are involved in the geological section of the Baida deposit. Natanebi bitumen is located in Western Georgia and belongs to the Middle Sarmatian fossil rocks.

To isolate the organic part of natural bitumen, extraction with chloroform was carried out in a Soxhlet apparatus for 52 hours. The extracts were filtered, the solvent was distilled off, and traces of the solvent were removed in a vacuum thermostat. Asphaltenes, tar and oils were isolated according to the standard method [16]. The yield, physico-chemical characteristics, elemental composition of the organic extract and the distribution of oils, resins and asphaltenes in it are shown in table 1.

Table 1. Characteristics of natural bitumen of Georgia

\begin{tabular}{|l|c|c|c|c|c|c|c|}
\hline Characteristics & Natanebi & Chibrevi & Baida & $\begin{array}{l}\text { Polpoy- } \\
\text { teibi }\end{array}$ & $\begin{array}{l}\text { Kari } \\
\text { Crossing }\end{array}$ & Mirzaani & $\begin{array}{l}\text { Kila- } \\
\text { Kupra }\end{array}$ \\
\hline Yield, mass \% & 31.7 & 38.1 & 34.0 & 35.1 & 14.2 & 32.5 & 41.0 \\
\hline Density, g/cm ${ }^{3}$ & 1.02 & 1.17 & 1.03 & 1.04 & 1.07 & 1.02 & 0.972 \\
\hline Molecular weight & 500 & 500 & 626 & 582 & 695 & 500 & 478 \\
\hline Softening point, ${ }^{0} \mathrm{C}$ & 11.0 & 9.5 & 40.8 & 57.0 & 73.5 & 11.8 & 8.5 \\
\hline \multicolumn{7}{|c|}{ Composition, mass \% } \\
\hline Oils & 32.8 & 27.2 & 37.0 & 39.1 & 28.3 & 67.7 & 55.2 \\
\hline Tar & 38.1 & 37.6 & 41.0 & 38.2 & 49.5 & 21.5 & 32.5 \\
\hline Asphaltenes & 29.1 & 25.2 & 22.0 & 22.7 & 22.2 & 10.8 & 12.3 \\
\hline \multicolumn{7}{|c|}{ Elemental composition, \% } \\
\hline C - carbon & 70.12 & 85.90 & 85.40 & 85.04 & 82.62 & 84.67 & 55.2 \\
\hline H - hydrogen & 11.73 & 9.82 & 9.65 & 10.1 & 9.32 & 10.0 & 32.1 \\
\hline S - sulfur & 3.56 & 0.62 & 1.25 & 0.58 & 1.18 & 0.3 & 12.3 \\
\hline N -nitrogen & - & 0.48 & 0.45 & 0.47 & 0.44 & 0.27 & - \\
\hline O - oxygen & - & 3.18 & 3.57 & 3.46 & 6.44 & 4.50 & - \\
\hline
\end{tabular}

The data in the table show that the yield of the organic part of natural bitumen ranges from $31 \%$ to 41\%. An exception is bitumen from Kari Crossing with a yield of $14.2 \%$. High oxygen content (6.44\%), density, softening temperature $(73.50 \mathrm{C})$, ash content and $\mathrm{C} / \mathrm{H}$ ratio indicate its deep oxidation.

It should be noted that, similarly to petroleum content of sulfur in Georgia's natural bitumen is low. By content of oils (27-39\%), natural bitumen, with the exception of Kila Kupra, belongs to asphalts, and Kila Kupra (55\% oil) belongs to malhtas.

Of the natural bitumen listed above, practical application adopted Natanebi bitumen which is periodically processed to produce road bitumen. Natanebi bitumen is a highly viscous mass with specific odor, with a pour point of $+9.70^{\circ} \mathrm{C}$ and an ignition temperature of $-138^{\circ} \mathrm{C}$, the point of start of distillation is $245^{\circ} \mathrm{C}$. The results of vacuum distillation of Natanebi natural bitumen and their elemental and group hydrocarbon composition are shown in table 2. According to the obtained data the concentration of aromatic hydrocarbons increases and concentration of cycloparaffin hydrocarbons decreases with an increase in the temperature of fraction, and paraffin hydrocarbons are absent.

Table 2. Characterization of Natanebi Bitumen Fractions

\begin{tabular}{|c|c|c|c|c|c|c|c|}
\hline \multirow{2}{*}{$\begin{array}{c}\text { Fractions, } \\
{ }^{0} \mathrm{C}\end{array}$} & \multirow{2}{*}{$\begin{array}{l}\text { Qutput, } \\
\%\end{array}$} & \multirow{2}{*}{$\begin{array}{l}\text { Density, } \\
\mathrm{kg} / \mathrm{m}^{3}\end{array}$} & \multicolumn{3}{|c|}{ Elemental composition, \% } & \multicolumn{2}{|c|}{ Hydrocarbon composition, \% } \\
\hline & & & $\mathrm{C}$ & $\mathrm{H}$ & $\mathrm{S}+\mathrm{O}_{2}+\mathrm{N}_{2}$ & aromatics & cycloparaffins \\
\hline $250-300$ & 3.02 & 891.0 & 85.91 & 13.89 & 0.24 & 18.5 & 85.5 \\
\hline $300-350$ & 6.8 & 926.0 & 87.36 & 12.06 & 0.58 & 48.5 & 51.5 \\
\hline $350-400$ & 5.9 & 949.0 & 86.75 & 12.94 & 0.31 & 54.0 & 46.0 \\
\hline $400-450$ & 8.9 & 966.0 & 88.52 & 11.15 & 0.33 & 68.4 & 31.6 \\
\hline $450-500$ & 7.3 & 975.0 & 88.36 & 11.25 & 0.37 & 61.7 & 38.7 \\
\hline
\end{tabular}

To identify the main aromatic structures of highly condensed compounds of natural bitumen, various hydrocarbon structural fragments were studied. In order to determine the aromatic structures included in the molecules of natural bitumen and their organic extracts, they were subjected to hydropyrolytic fragmentation according to the technique developed in the Laboratory of Petroleum Chemistry [11]. The hydropyrolysis process was carried out at a temperature of $450^{\circ} \mathrm{C}$ and duration of the process was 4 hours. Solutions of hydropyrolysates in dioxane were analyzed by gas-liquid 
chromatography on a three-meter column with chromosorb W (liquid phase OV-101\%). The results of gas-liquid chromatography are illustrated in Figure 2.

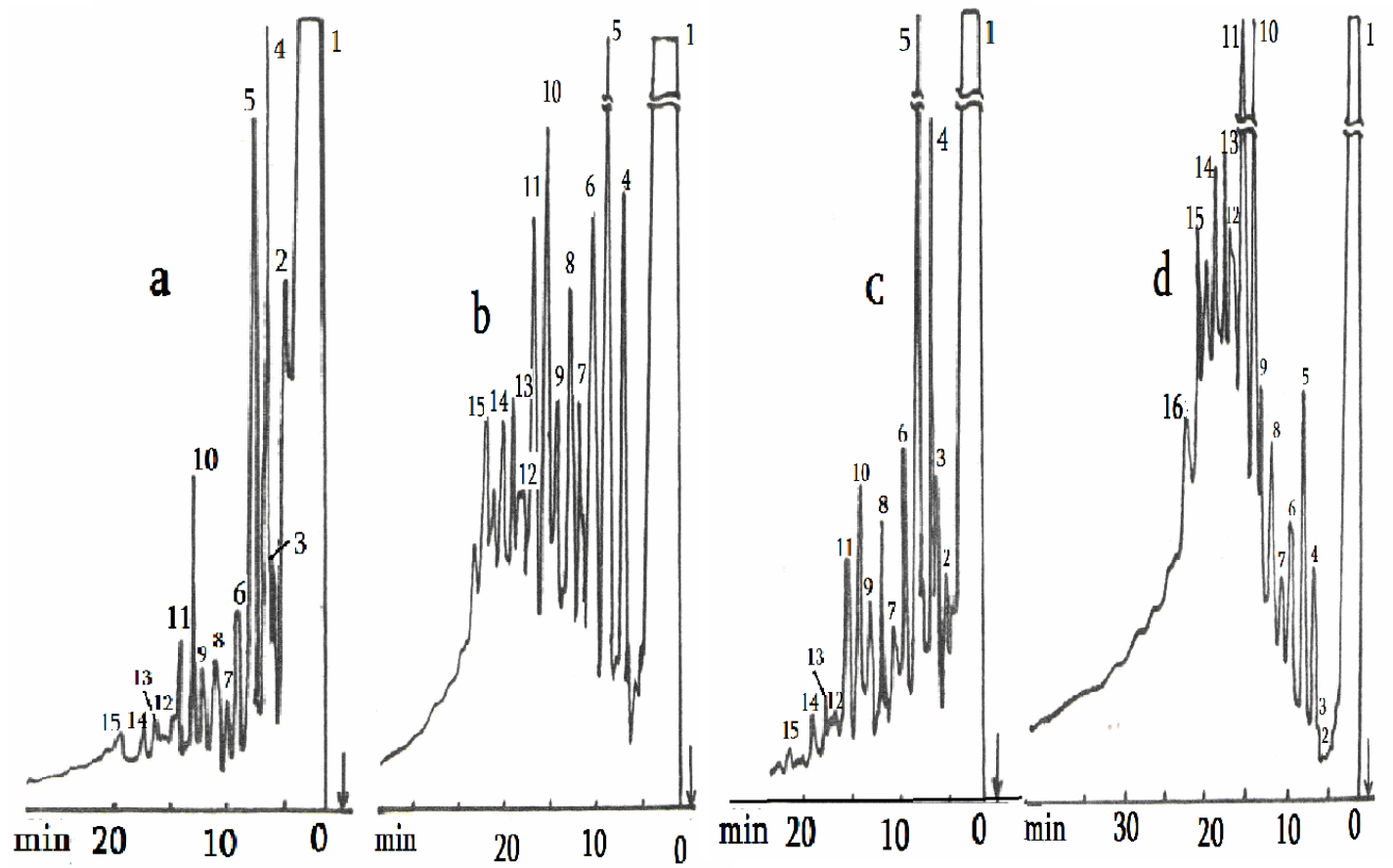

Fig. 2. Chromatograms of Georgian natural: Kari Crossing (a), Chibrevi (b), Baida-2 (c), Natenebi(d) 1 -dioxane, 4-naphthaline, 5 - methylnaphthaline, 6 -diphenyl, 8-fluorene, 10 - phenanthrene, 11 - methylphenanthrene, 13 - pyrene, 15 - chrysene.

Temperature of the analysis $100^{\circ} \mathrm{C} \rightarrow 10^{\circ} \mathrm{min} . \rightarrow 325^{\circ} \mathrm{C}$.

A comparison of the chromatograms of the mentioned above bitumens shows that they are almost identical and consist of the same peaks, among which were identified: naphthalene, methylnaphthalene, phenanthrene, methylphenanthrene, diphenyl, fluorene, pyrene and chrysene.

A study of the trace element composition of natural bitumen was carried out by method of direct burning of their organic extracts. Ash extracts were analyzed on an emission spectrometer. The results are shown in table 3 .

Table 3. Quantitative-spectral analysis of natural bitumen

\begin{tabular}{|c|c|c|c|c|c|c|c|c|c|c|c|c|c|c|}
\hline \multirow{2}{*}{ area } & \multicolumn{14}{|c|}{ The content of trace elements in ash, \% } \\
\hline & $\mathrm{Sr}$ & Ba & V & $\mathbf{C r}$ & $\mathbf{N i}$ & Ti & $\mathbf{C u}$ & Mn & Co & $\mathbf{P b}$ & Mo & $\mathbf{B e}$ & $\mathbf{Z r}$ & V/Ni \\
\hline Chibrevi & $0^{\circ}$ & $0^{\circ}$ & $\stackrel{0}{=}$ & ชิ & $\stackrel{\infty}{0}$ & $\overrightarrow{0}$ & ชิ & m. & 。 & $\frac{0}{0}$ & $\bar{m}$ & $\overrightarrow{0}$ & $\overline{0}$ & 工 \\
\hline $\begin{array}{c}\text { Kari } \\
\text { Crossing }\end{array}$ & $\stackrel{+}{0}$ & กิ & $\stackrel{+}{0}$ & ช̃ & $\overrightarrow{0}$ & ชิ & $\overline{0}$ & $\stackrel{+}{0}$ & : & 0 & $\tilde{8}$ & $\overline{0}$ & $\overrightarrow{0}$ & $\hat{0}$ \\
\hline Baida & $\tilde{0}$ & $\overrightarrow{0}$ & $\because$ & ชै & กิ & है & m. & $\stackrel{+}{0}$ & \& & ¿̂. & ठै. & ô & $\overline{0}$ & 3 \\
\hline $\begin{array}{l}\text { Polpoy- } \\
\text { teibs }\end{array}$ & $\stackrel{0}{0}$ & กั & ô. & 훙 & กั & กั & กั & $\stackrel{\infty}{0}$ & 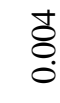 & ఠิ & 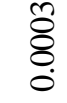 & \&̊ & ô. & $\tilde{0}$ \\
\hline Mirzaani & $\stackrel{8}{0}$ & ¿̊. & : & : & $\stackrel{0}{0}$ & กั & $\stackrel{t}{0}$ & $\stackrel{+}{0}$ & ن் & $\overbrace{0}^{2}$ & $\tilde{\delta}_{0}^{0}$ & $\tilde{\delta}_{0}^{0}$ & ठิ & Iִ \\
\hline $\begin{array}{l}\text { Kila- } \\
\text { kupra }\end{array}$ & $\ddot{0}$ & 움 & ¿. & : & ¿̊. & $\overline{0}$ & $\stackrel{\overbrace{}}{0}$ & : & $\stackrel{\infty}{0}$ & $\stackrel{0}{0}$ & $\bar{\delta}_{0}$ & ఠิ & $\stackrel{8}{\circ}$ & $\frac{\infty}{0}$ \\
\hline
\end{tabular}


From the data given in table 3 it can be seen that natural bitumen contains all elements characteristic to Georgian petroleum, but in higher concentrations. In most bitumen as well as in opetroleum, the ratio $\mathrm{V} / \mathrm{Ni}<1$ shows that they are of tertiary age. Chibrevi and Mirzaani bitumens with a V/Ni ratio> 1 indicate that they belong to more ancient Paleozoic type [17].

\section{Conclusions.}

- The presence of the same aromatic structures of natural bitumen and high-boiling petroleum products indicates the existence of a genetic link between petroleum and natural bitumen.

- In hydropyrolithysates of natural bitumen are identified: naphthalenes, biphenyls, fluorenes, phenanthrenes, pyrenes, chrysenes, perilenes, benzchryzenes, benzperylenes.

- By stratigraphic correlation of bitumen and according to the ratio $\mathrm{V} / \mathrm{Ni}<1$ in most natural bitumen it was established they are of tertiary age. The ratio $\mathrm{V} / \mathrm{Ni}>1$ for bitumen of Chibrevi and Mirzaani indicates their more ancient Paleozoic type origin.

\section{REFERENCES}

1. Yermolaev D.V. Prospects for Bitumen as an Alternative Fuel. Innovative Solutions in Alternative Energy and Ecology. 2010, \#7, v.87. p. 121-124.

2. Khetsuriani N., Usharauli E., Goderdzishvili K., Chkhaidze M. Natural bitumen and perspectives of their usage. Georgia Chemical Journal, 2008, 3(1), p.66-69.

3. Oil-bituminous rock. Materials of All-Union conference, Alma-Ata, Kazakh SSR, "Nauka" 1982, p. 296.

4. Rubnitski V.M. Natural bitumen: State of resource - features of development, opportunities of usage, Geology of petroleum and gas, 1997, \# 2, p. 4.

5. Iskritskaia M.I. Economic expediency of usage of natural bitumen deposits. Oil-gas industry, 2007, 1 (29), p.4

6. Tisso B., Velte D. Formation and distribution of crude oil. Moscow, "Mir", 1981.

7. Usharauli E., Khetsuriani N., Topuria E., Goderdzishvili K., Mchedlishvili I., Shatakishvili T. Natural bitumen as alternative to petroleum source. Proceedings of the Petre Melikishvili Institute of physical and organic chemistry. Tbilisi, 2011, p. 103-107.

8. Geology of the USSR, v. 4, Georgian SSR, Treasures of the soil, Moscow, "Nedra", 1974.

9. Okromchedlidze G., Bardzimashvili D., Gongliashvili Z. Geological-Hydrogeological ground of development of the source of raw materials from Shromisubani-Tskaltsminda petroleum deposit, Tbilisi, Crude oil and Gas of Georgia. 2005, \# 13, p. 25-43.

10. Ebralidze T., Gongliashvili Z. Geochemical characterization of Jurassic precipitations and possibilities of hydrocarbon generation in them. Georgian crude oil and gas. Tbilisi, 2005, \# 13, p. 86-92.

11. Usharauli E., Melikadze L., Kortava L., Topuria E. Investigation of aromatic fragments of natural bitumen of Georgia. Bulletin of the Georgian Academy of Sciences, 1990, 137, \# 3, p.4.

12. Usharauli E., Goderdzishvili K., Topuria E., Chkhaidze M., Gongliashvili Z. About natural bitumen of Georgia. Abstracts of the $7^{\text {th }}$ International Mamedaliev conference, Baku, 2009, p. 133-134.

13. Usharauli E., Kortava L., Mchedlishvili I., Goderdzishvili K. Aromatic fragments of resin-asphaltene substances of petroleum and natural bitumen. Proceedings of the International petrochemical conference dedicated to the $100^{\text {th }}$ anniversary from the birth of academician L.Melikadze, Tbilisi, 2012, p. 111-115.

14. Khisamov R.S., Gatiatullin N.S., Shargorodski I.E. Geology and Development of Natural Bitumen Pools of Tatarstan Republic. Kazan, Publisher-house "Fen" 2007, 295 p.

15. ASTM D3279-07. (2007). Standard Test Method for n-Heptane Insolubles, Philadelphia PA, Available from http://www.astm.org/Standards/D3279.htm (1) Petroleum Asphaltenes. Available from: https://www.researchgate.net/publication/221926634_Petroleum_Asphaltenes [accessed May 05, 2018].

16. Modern methods for petroleum researches (reference book), 1984, Nedra, 430p. Bogomolov A.I., Temianko M.B., Khotintseva L.I.

17. Melikadze L.D., Goderdzishvili K. G. (1971). Photochemical concentration of ash-forming elements in crude oil and oil products. Elsevier, v.11, issue 2, pp.120-124. 